\title{
Correction to: Sphenopalatine Ganglion Block in the Management of Chronic Headaches
}

Jeffrey Mojica ${ }^{1} \cdot \mathrm{Bi} \mathrm{Mo}^{1} \cdot$ Andrew $\mathrm{Ng}^{1}$

Published online: 20 November 2017

(C) Springer Science+Business Media, LLC, part of Springer Nature 2017

Correction to: Curr Pain Headache Rep (2017) 21: 27 https://doi.org/10.1007/s11916-017-0626-8

The original version of this article contains an error in an author's first name. The spelling of Dr. Mojica's first name should read "Jeffrey" instead of "Jeffery." The correct author name is presented above.

The online version of the original article can be found at https://doi.org/ 10.1007/s11916-017-0626-8

Andrew Ng

Andrew.Ng@jefferson.edu

1 Jefferson Pain Center, Department of Anesthesiology, Thomas Jefferson University Hospital, Philadelphia, PA 19107, USA 